\title{
A Bird's Eye View over a Scandinavian Isogloss Exponence of Definiteness (in Word Prosody)
}

\author{
Miguel Vázquez-Larruscaín
}

\begin{abstract}
The articulation of definiteness in the Scandinavian languages displays an intricate and complex pattern where all levels of grammar are involved. In addition, there is considerable variation at all of these levels, not only across languages and varieties, but also across different constructions within a single variety. In the first half of the paper, the rich information already available on these topics is first put together. In the second half, the variation found in the prosodic realization of definiteness at the word level receives an optimality-theoretic treatment in more detail. The goal is to reduce the quite intriguing variation in the prosody of definiteness to the factorial typology of two structural constraints, namely ONSET and ALIGNMENT(suffix, foot), when everything else remains (more or less) equal.
\end{abstract}

\section{Keywords}

definiteness, Scandinavian accent, word prosody, factorial typology, variation, optimality 


\section{Introduction}

Overt exponence of morpho-syntactic definiteness in Scandinavian exhibits a varied sample of structural patterns at many levels. This paper is a call for the map of this rough linguistic landscape. Thus, $\S 2$ intends to live up to the promise of the title, using parametric criteria from all levels of grammar - from the syntactic configuration of definite noun phrases all the way down to the phonetic realization of the definite suffixes, via a plethora of morpho-lexical, morpho-syntactic, morpho-phonological and phonological patterns in between.

From $\$ 3$ onwards, the focus is on prosodic variability. Four types connect the outermost corners of Continental Scandinavia, comprising the three national languages. North Djurslandic, a traditional Danish dialect in the northeastern part of Jutland, also plays a significant role, both as a geographical and structural point of reference. North Djurslandic morpheme-stød, an isolate in previous typologies (EJSKJÆR 1990), comes to fill in a gap in a factorial typology based on two basic principles: ONSET preferences (PRINCE \& SMOLENSKY 2004), and prosodic subcategorization -expressed as ALIGNMENT constraints (McCARTHY \& PRINCE 1993, McCARTHY 2006). Furthermore, the integration of morpheme-st $\phi d$ in the general picture of North Scandinavian word prosody also sheds light on the phonology of Danish stød at large (BASB ØLL 2005, 2008). To the extent that the prosody of definiteness in Scandinavia can be reduced to a few languageindependent principles, soft violable constraints become an indispensable tool for not only theory-oriented and typological research -where their presence is already firmly established, but also the variationist program.

\section{The Exponence of Definiteness: Variability from tip to toe}

This section is a preliminary catalogue of the exponence of definiteness in both noun phrases and noun paradigms all over Scandinavia, with the intention to review the information available for all grammatical levels and interfaces involved. Previous typological work in the area of syntax, as well as traditional research on the morphology of traditional dialects, or in the study of prosody and accent, as well as in the phonology of the suffix itself, still needs to be enriched in order to cover the entire territory in all its complexity in an integrated fashion.

\subsection{Syntactic variation}

The pattern of syntactic variation in noun phrases is by now well known in its fundamental lines. Four classic types stand out (DAHL 2012).

(1) Phrasal exponence of definiteness
a. Suffixation only: gamla (DEF) húsið (DEF)
(Icelandic)
b. Compounding: gammhuse (DEF)
(traditional North Swedish) 
c. Split definiteness: det (DEF) gamle (DEF) hus

d. Double definiteness: det (DEF) gamle (DEF) huset (DEF)
(Danish)

(Norwegian)

The richness of (1) does not exhaust the topic. More variation is found within all linguistic areas and national borders, across dialects or just across constructions within the same dialect. For instance, a most distinguished exceptional type of DP is found in the west coast of Jutland, in Denmark. While Mainstream Danish follows the Scandinaviantype, with suffixation, traditional West and Southern Jutlandic dialects prefer the West Germanic way of signaling definiteness with a proclitic determiner (DAHL 2012).

(2) Geographic variation in Danish definite noun phrases
Danish, "the house"
a hus (W \& S Jutland)
huset (standard)

Also, definiteness can be implemented in a construction-specific fashion in the same language, as illustrated by comparing attributive, demonstrative and possessive noun phrases in Swedish, Norwegian, and Danish (3). While Danish is consistent in avoiding double definiteness in every construction, Swedish avoids double definiteness in both demonstrative (proximal) and possessive phrases, while Norwegian bokmål is systematic in avoiding the double definiteness pattern only in the possessive construction if the possessive is pre-posed (SVENONIUS 1992).

(3) Language-internal variation in the syntax of definiteness

\begin{tabular}{|c|c|c|c|}
\hline DEM & $\begin{array}{l}\text { Danish } \\
\text { dette hus }\end{array}$ & $\begin{array}{l}\text { Swedish } \\
\text { detta hus }\end{array}$ & $\begin{array}{l}\text { Norwegian, bokmål } \\
\text { dette huset }\end{array}$ \\
\hline b. POSS & mit hus & mitt hus & mitt hus \\
\hline ATTR & det gamle hus & det gamla huset & det gamle huset \\
\hline
\end{tabular}

Many varieties of Norwegian, in their turn, are quite permissive with word order alternatives in the possessive phrase, where pre- or postposing the possessive correlates with the absence or presence of the definite suffix in the noun, respectively.

(4) Variation in Norwegian possessive DP

Norwegian, "my house" mitt hus $(*$ et) hus*(et) mitt

\subsection{Morphosyntactic variation}

In the noun paradigm, definiteness interacts with gender and number in various ways. This variability is particularly rich in traditional dialects, while standard, urban and coastal varieties usually exhibit a more uniform typology (SANDØY 1998). Below are several syncretisms of gender in definite plural forms (reconstructed from HELLEDAN \& PAPAZIAN 1981, henceforth H\&P81; PAPAZIAN \& HELLELAND 2005, and SANDØY $1985,1996)$ 
(5) Syncretism of gender in plural definite forms of Norwegian varieties

$\begin{array}{lllll} & & \text { HATT } & \text { SOL } & \text { HUS } \\ \text { a. All different (Nynorsk) } & \text { hattane } & \text { solene } & \text { husa } \\ \text { b. Masc = Fem (Bokmål) } & \text { hattene } & \text { solene } & \text { husa } \\ \text { c. Masc = Neuter (Troms) } & \text { hattan } & \text { solen } & \text { husan } \\ \text { d. All the same (Sørlandet) } & \text { hattan }(e) & \text { solan }(e) & \text { husan }(e)\end{array}$

\subsection{Morpholexical variation}

Continental Scandinavian has seen a progressive loss of many of the arbitrary declensional classes of Old Norse, still alive in Modern Icelandic and Faroese morphology. In Mainland Scandinavian, the preservation of weak and strong declensions is only to be found in rural interior traditional dialects of Norway and Sweden, while the contrast is completely lost in all dialects of Danish. The loss of declensional classes is virtually complete in all urban varieties of Norway, with Egersund, on the southwest coast, as the only exception (Jan Hognestad, p.c.). In coastal dialects and urban speech the noun paradigm is exclusively determined by the interplay of gender and number with the prosodic properties of the noun (reconstructed from H\&P81), with minimal traces of arbitrary declensional classes in the system.

(6) Morpholexical variation in Western Norway for definite singular of feminine nouns
a. Bergen $\left(\right.$ urban $\left.^{1}\right)$
b. Kristiansand (urban)
c. Hordaland (coastal)
d. Voss \& Hardanger (rural)
e. South Rogaland (rural)
f. Inland Sogn (rural)

$\begin{array}{ll}\text { SOL } & \text { JENTE } \\ \text { solen } & \text { jenten } \\ \text { sola } & \text { jenta } \\ \text { solå } & \text { jentå } \\ \text { sole } & \text { jentå } \\ \text { sola } & \text { jentå } \\ \text { soli } & \text { jentå }\end{array}$

\subsection{Morphological variation}

In addition to lexical and structural variation, there are also conspicuous differences on the actual selection of morphs, both within and across varieties. Morph selection is another relevant dimension in classifying a dialect. In (7) we compare three rural dialects of Norway that share a morpho-lexical partition of feminine nouns into strong and weak classes, but those dialects differ in the selection of morphs for the same words of the same class. We illustrate this with the strong feminine noun SOLEN, "the sun".

(7) Morph-selection as a distinguishing isogloss. SOLEN (strong class, fem, sg, def)
a. Voss
$[[æ]]$
sole
b. Hallingdal
$[[\mathrm{e}]]$
sole

1 I thank an anonymous referee for help with these data. Responsibility comes back to me after checking. 

c. Romsdal
$[[\mathrm{a}]]$
sola
d. Inland Sogn
$[[i]]$
soli

On the contrary, some varieties may share the same morph for the same morphological category, but yet differ in the internal organization of the category taken as a whole. For instance, the speech of Oslo and the traditional dialects of Romsdal both select the same morph [[a]] for the singular definite of most feminine nouns. However, in Oslo, the same morph is used to mark definiteness in all feminine nouns, while in Romsdal the suffix of strong feminine nouns [[a]] has a competing allomorph [[å]] in the inherited weak feminine class.

(8) Morph-selection as a shared isogloss

Strong Feminine Def $\mathrm{Sg} \quad$ Weak Feminine Def $\mathrm{Sg}$ SOL JENTE
a. Oslo (urban)
[[a]] sola
$=\quad$ jenta
b. Romsdal (rural)
[[a]] sola
[[̊̊]] jentå

\subsection{Morpho-phonological variation}

Another area of major interest for current theories is the study of prosodic alternations. There are several dimensions involved, but for reasons of space I will restrict the data to the four types to be discussed in the second part of this paper, see $\$ 4$.

(9) Different patterns of prosodic alternation in utrum definite singular of disyllabic bases
a. Swedish
$\mathrm{SOFA}+\mathrm{N}$
$\mathrm{KAKE}+\mathrm{N}$
b. Norwegian
[ ${ }^{1}$ sof:an]
[ $\left.{ }^{2} \mathrm{ka}: \mathrm{kan}\right]$
c. Danish
[ ${ }^{1}$ so:fa.n]
[2ka:kn]
d. North Djursland
['so: fæ:?.n]
['kæ:n]
['so: f $\mathrm{f}:$ ? $\cdot \mathrm{n}]$
['kæiii?.n]

\subsection{Phonological variation}

Once the morphs that expose definiteness are selected and spelled out according to grammatical context, there is still room for more variability depending on the phonological context that definite suffixes happen to dock in. This subsection is based on KRISTOFFERSEN's 2007 schematic typology of the singular utrum -en in standard accents of Norwegian ${ }^{2}$. The focus is on how the nature of the stem-final consonant determines whether the exponent -en is to be realized with a schwa followed by a sonorant [ən], or rather coalesce into a syllabic sonorant [n].

2 A more detailed presentation of the phonology of definite suffixes in Norwegian can be found in Kristoffersen 1991, and 2000. For Swedish, the interested reader can consult Riad 2003 and references therein. 
(10) Variable schwa deletion in the exponent of singular definite utrum

\begin{tabular}{|c|c|c|}
\hline & \multicolumn{2}{|c|}{$[+ \text { cor, }- \text {-son }]_{-}[- \text {cor, }- \text {-son }]_{-}$} \\
\hline & hatten & sekken \\
\hline Airport Nwg & ['hat:ən] & ['sck:ən] \\
\hline b. Western Nwg & ['hat:n] & ['sck:ən] \\
\hline c. Eastern Nwg & ['hat:n] & ['sck:n] \\
\hline
\end{tabular}

\subsection{Phonetic variation}

The pattern described in (10) is obviously an idealization, as it is well-known that the variability of actual data at the phonetic level, even within a single idiolect, is considerable. The role of the phonological analysis is nevertheless indispensable, in my view, to confront variation in real speech - the phonological analysis showing the direction of the trend. In the specific case of (10), the prediction is clearly of an implicational nature, such that even if a speaker of say Western Norwegian does not exhibit a uniform realization of the same suffix in the same context, as it will probably be the case, the very same speaker will most likely vary quantitatively in an orderly way, such that the proportion of schwa suppression with respect to schwa maintenance will always be higher when following a coronal obstruent than after a non-coronal consonant, see (11), everything else being equal.

(11) Phonetic variability
a. Western Norway:
b. Eastern Norway:

$$
\begin{aligned}
& \mathrm{p}\left(\mathrm{n} / \mathrm{en},[+\mathrm{cor},- \text { son }]_{-}\right)>\mathrm{p}\left(\mathrm{n} / \mathrm{en},[+ \text { cor, }- \text { son }]_{-}\right) \\
& \mathrm{p}\left(\mathrm{n} / \mathrm{en},[+\mathrm{+} \text { cor, }- \text { son }]_{-}\right) \geq \mathrm{p}\left(\mathrm{n} / \mathrm{en},[+ \text { cor, }- \text { son }]_{-}\right)
\end{aligned}
$$

\section{Prosodic Morphology}

Prosodic-morphology is a research program launched by McCARTHY \& PRINCE (1986) to explore phonology and morphology in interaction. A major goal is to reduce morphological operations to prosodic principles, both language and construction-independent. Analyses conducted under such premises, if superior to alternative approaches with less unified or integrated resources, aspire to significant theoretical progress in our understanding of this fundamental area of the language-faculty. This paper intends to contribute to the same program with Scandinavian material.

A brief illustration of suffixation in Axininca Campa (Arawakan, Peru) can be as good an example as one can imagine (McCARTHY 2006) to introduce the prosodico-morphological approach. Among other things, Axininca Campa exhibits a curious asymmetry in the suffixation of monomoraic bases, see (12). While consonant-initial suffixes induce augmentation of monomoraic bases with one extra syllable, TA, vowel-initial suffixes, in their turn, only induce consonant epenthesis, $\mathrm{T}$, and the base remains monomoraic. Bases with more than one mora never undergo syllabic augmentation of the stem, retaining a common prosodic shape. 
(12) Aixininca Campa
a. Consonant initial suffix
Root: na + Suffix: piro = na.TA.pi.ro
b. Vowel initial suffix
Root: to + Suffix: a:nts ${ }^{\text {hi }}=$ to.Ta:.nts ${ }^{\text {hi }}$

Case (12a) inserts a whole syllable to satisfy the prosodic Minimality Condition (WMin) that the stem be a whole prosodic word (13b), that prosodic words contain at least one metrical foot, and that metrical feet be minimally binary at the moraic or syllabic level (13c). Case (12b), on the other hand, does not respect the Minimality Condition -the morphological base remains monosyllabic, but it nevertheless obeys the Syllabic Ideal of avoiding hiatus, thanks to an epenthetic consonant that breaks the newly created hiatus, when the stem ends in a vowel and this vowel is followed by a suffix-initial vowel. A superficial look at (12a) and (12b) could lead the analyst to conclude that ONSET (13a) is an explanatory principle, while Word Minimality conditions achieves nothing in Axininca, based on the evidence provided by (12b). However, rejecting Word Minimality effects nevertheless comes at a cost, since a great deal of what goes on in (12a), without FT-BIN $_{\text {MIN }}$, remains an arbitrary parochial contingency.

(13) Principles of Prosodic Form

a. ONSET "Syllables have onsets"

b. ALIGN_R(stem, p-word) "Right edge of stem aligns to right edge of p-word"

c. FT-BIN ${ }_{\mathrm{MIN}}$ "Feet are minimally binary at either the moraic or syllabic level"

Optimality Theory is adamant in assigning a role to solid principles in every language, even in the light of clear exceptions. For the purpose, principles are soft, formalized as violable constraints arranged with different strengths in language-specific hierarchies. Thus, linguistic structures are not expected to satisfy all conditions -a logical impossibility when different conditions impose contradictory demands on the same candidate. Grammatical structures are therefore not perfect, but optimal, in such a way that the violation of any principle can still be justified if that violation affords the satisfaction of a higher ranked constraint in the language-specific hierarchy. The ultimate ideal is to leave no room for either language or construction-specific idiosyncratic laws. I will now present a peremptory analysis of cases (12a) and (12b) with a standard OT tableau ${ }^{3}$. For clarity, I will also introduce the classic DEP-C, against the insertion of epenthetic consonants on output representations. This constraint will split into a single and a self-conjoint version, DEP-C ${ }^{2}$, which will only penalize candidates violating DEP-C twice (SMOLENSKY 1995). The toy-hierarchy for Axininca Campa is accordingly DEP-C ${ }^{2}$, FT_BIN/WMin > ONSET 》 ALIGN_R(stem,p-word), DEP-C

3 This peremptory analysis has no other purpose than illustrate the interaction of violable constraints. I have no claims whatsoever to make about Axininca Campa. I take this license for expository purposes only. 
(14) Root: na + Suffix: piro = na.TA.pi.ro

\begin{tabular}{|l|l|l||l||l|l|}
\hline \{na+piro\} & FT-BIN & DEP-C & ONSET & ALIGN_R & DEP-C \\
\hline \hline a. (naTA)piro $\sqrt{ }$ & & & & $*$ & $*$ \\
\hline b. (na)piro & $*$ & & & & \\
\hline
\end{tabular}

(15) Root: to + Suffix: a:nts ${ }^{\mathrm{h}} \mathbf{i}=$ to.Ta:nts ${ }^{\mathrm{h}} \mathbf{i}$

\begin{tabular}{|c|c|c|c|c|c|}
\hline$\left\{\right.$ to $+a: n^{h}$ i $\}$ & FT-BIN & DEP-C ${ }^{2}$ & ONSET & ALIGN_R & DEP-C \\
\hline a. (toTa:ntshi) $\sqrt{ }$ & & 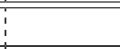 & & $\%$ & $*$ \\
\hline b. (to.a:ntshi) & & 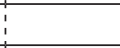 & $*$ & $*$ & 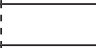 \\
\hline c. (to)Ta:ntshi & * & $\vdots$ & & & $*$ \\
\hline d. (toTa)a:ntshi & & 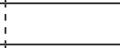 & * & $*$ & $*$ \\
\hline e. (toTa)Ta:ntshi & & : & & $\%$ & $* *$ \\
\hline
\end{tabular}

\section{The Prosodic Map of Definiteness in Scandinavian: Variability from coast to coast}

This paper focuses on salient prosodic properties of definite words in four varieties of Mainland Scandinavia, as presented in $\$ 2.5$ above. Those types cross the whole Scandinavian area from coast to coast, from Jutland in Denmark (9d) to Lake Mälaren in Sweden (9a). The selection is based on not only geographical spread but also structural salience in a factorial typology. The inclusion of North Djurslandic, together with the three national languages, serves two different goals. On the one hand, the North Djurslandic morpheme-stød highlights the structural consistency of the sample, contesting its previous labeling as "the most curious stød" (EJSKJÆR 1990). On the other hand, North Djurslandic sheds light on the common and standard grammar of Danish stød, revealing the necessary presence of prosodic subcategorization in the phonological realization of definite nouns. This paper contends that the grammar of stød as we know it (BASBØLL 2005) must be complemented with the prosodic subcategorization of suffixes along the lines of $\S 3$. This idea is central to our analysis.

In the following sections the prosodic variability of definite nouns will emerge from the interplay of four universal prosodic and morphological principles (plus a version of the $\mathrm{OO} /$ prosodic_type indexed for the traditional type of $\beta$ words, namely disyllables without a full vowel in their final unstressed syllable, as characterized in ANDERSEN \& HJEMSLEV 1967).

4 Many ideas in this paper have roots in the Danish tradition on the study of word accent. In constraint (16e) I appeal to the word prosodic taxonomy of the glossematic school, which divided the entire vocabulary into three main classes: class $\alpha$ comprises monosyllables and oxytonic words, $\beta$ is made up of disyllables and paroxytonic words, $\gamma$ is the default class. From BASB $\varnothing$ LL 2005 I take his Stød and Non-Stød principles: (i) stressed syllables receive stød, (ii) $\beta$ words are general exceptions to (i). Disyllables and paroxytonic words with stød (cf. huset, bilen, etc) must be morphologically complex, or lexically marked for stød, cf. Basbøll's Lexical Stød Principle. In my view, definite suffixes involve a special Alignment constraint that demands the syllabic suffix to be attached after the right edge of a prosodic word. On the contrary, indefinite plurals are parsed as part of the nuclear prosodic word, becoming regular $\beta$ words without stød in their majority (GR $\varnothing \mathrm{NNUM \text {, }}$ 
(16) Constraints
a. ONSET "syllables have onsets"
b. HAVE- $\sigma(u)$ "phonological material in correspondence to a certain suffix $u$ should contain at least a [+syllabic] element"
c. ALIGN_L-R(suffix $(u)$, foot) "align the left edge of the syllable that contains the suffix $u$ against the right edge of a foot preceding it"
d. OO/prosodic_type "preserve the prosodic shape of the base in derivation"
e. OO/prosodic_type ${ }_{\beta}$ "preserve prosodic shape when bases end in levissima"5

Insular Scandinavian provides the starting point for our factorial typology - also from a diachronic point of view, since the current situation in Icelandic arguably reflects the general situation before a series of transformations began to take place in the continent centuries ago.

(17) Phonological realization of the Definite Masculine Suffix in Icelandic, -in-/-n-
a. hatturinn
\{hat: - r + in - r $\}\left[\right.$ ha $\left.^{\mathrm{h}} \mathrm{tYri}{ }^{\mathrm{d}} \mathrm{n}\right]$
b.
HAT. NOM-SG-MASC-STRONG + DEF. NOM-SG-MASC
c. hattana
[hat: - a + in - a\} [ha hana]
d.
HAT. ACC-PL-MASC-STRONG + DEF. ACC-PL-MASC

Concerning the alternation -in-/ $\mathbf{- n}$-, the following constraint ranking is assumed: ONSET > MAX-V. When ONSET is satisfied, the suffix is realized as -in-, see (18a), since the alternative -n- violates MAX-V for no gain, see (18b). MAX-V obviously penalizes the loss of vowels.

(18) $-i n-$

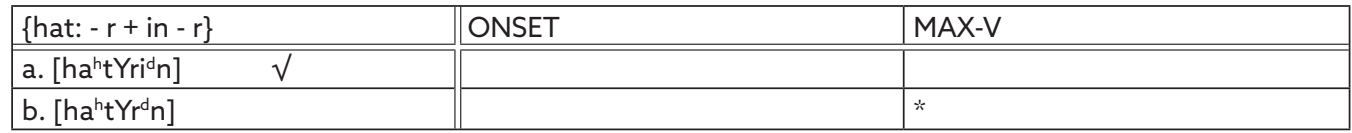

VÁZQUEZ-LARRUSCAÍN \& BASBØLL 2013). This means that the morphological Alignment constraint must be indexed to distinguish between the clitic-like and the internal suffixes. This is an assumption that for reasons of space cannot be implemented in the body of this paper, but I think that the gist of it should not be problematic. In this respect, constraint indexing does the job that stratal segregation played in Lexical Phonology.

5 The distinction between $\alpha$ and $\beta$ words plays a significant role on the assignment of word accent, see previous footnote. In the analysis of Danish, the same prosodic distinction is also crucial for the study of stød alternations, as well as for connecting the main Danish type with the dialectal facts of North Djursland. These connections, which as far as I can see are here presented for the first time, require a further distinction within the group of disyllables and paroxytonic words, taking into consideration the nature of the vowel of the final unstressed syllable. One group is characterized by having schwa, also called levissima. The other group has full vowels in their final unstressed syllables. The interesting correlation, central to this paper, is that patterns of alternating secondary stød are sensitive to this distinction in standard Danish, see (29) and (30), while in North Djursland they are not, see (32) and (33). This is the reason behind constraint (16e). There are many details that need further elaboration of this idea, but the purpose of my analysis is to highlight the potential value of these observations from a theoretical point of view rather than to present a full-blown analysis of all the prosodic, lexical and morphological complexities involved in the comparative study of Scandinavian word accents at large. There is a trade-off to be made and I beg the reader to bear with me whenever matters of detail, interesting as they are, are simply alluded to, when not plainly overseen, in order to preserve the unity and the coherence that emerges from the interaction of elementary mechanisms in the comparative picture. 
However, when ONSET is at stake, the -n- version of the suffix is chosen, at the expense of losing a vowel in the winning candidate (19a).

(19) $-n$ -

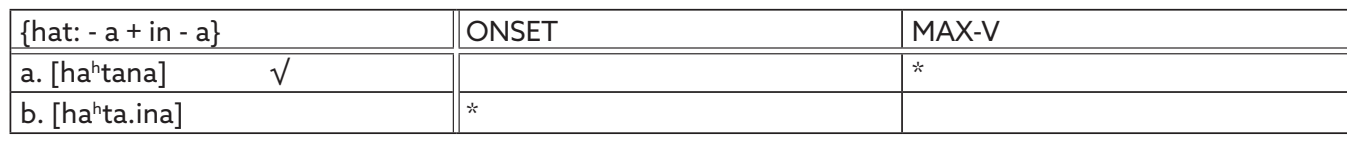

\subsection{Swedish}

Swedish, like Insular Scandinavian, keeps ONSET on top. The alternation now is normally between a syllabic and a non-syllabic nasal, -n/-n. Arguably the suffix is syllabic to satisfy HAVE- $\sigma$, see (20a), while it is non-syllabic whenever the base ends in a vowel, satisfying ONSET by avoiding hiatus ${ }^{6}$, as in (21a).

(20) baren

\begin{tabular}{|l||l|l|}
\hline$\{$ ba: $r+n\}$ & ONSET & HAVE- $\sigma$ \\
\hline \hline a. $[$ ba:.rn] $\sqrt{ }$ & & \\
\hline b. $[$ ba: $r n]$ & & $*$ \\
\hline
\end{tabular}

(21) snön

\begin{tabular}{|l||l|l|}
\hline$\{$ snø: $+n\}$ & ONSET & HAVE- $\sigma$ \\
\hline \hline a. [snø:n] $\sqrt{ }$ & & $*$ \\
\hline b. [snø:.n] & $*$ & \\
\hline
\end{tabular}

Vowel-final disyllabic bases indicate that in addition to the subhierarchy ONSET > HAVE- $\sigma$, a second ranking, namely OO/p-type 〉 ALIGN-L-R, must also be present.

(22) $\mathrm{kakan}^{7}$

\begin{tabular}{|c|c|c|c|c|}
\hline$\left\{{ }^{2} k a: k a+n\right\}$ & ONSET & 00/p-type & HAVE- $\sigma$ & ALING_L-R \\
\hline a. $\left[{ }^{2} \mathrm{ka}: \mathrm{kan}\right] \sqrt{ }^{7}$ & & 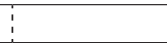 & $*$ & $*$ \\
\hline b. $\left[{ }^{2} \mathrm{ka}: \mathrm{ka}: \mathrm{n}\right]$ & & * & $*$ & \\
\hline c. [ $\left.{ }^{2} \mathrm{ka}: \mathrm{ka}: . \mathrm{n}\right]$ & * & $3 *$ & & : \\
\hline d. [ ["ka:ka.n] & $*$ & 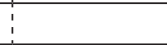 & & : * \\
\hline
\end{tabular}

The behavior of disyllables with a full vowel on the final syllable, cf. (23a) and (23b) below, resolves the indeterminacy of the ranking between ONSET and OO/p-type to the former's favor. Candidate (23b) respects both OO/p-type and HAVE- $\sigma$, but yet loses to

6 The Swedish pattern is certainly more complicated than we can cover in this paper, as discussed in Riad 2003. Some nouns of common gender opt for non-syllabicity in contexts where ONSET is not at stake, say natur'n "the nature" instead of *naturen. The syllabicity of the neuter suffix is also more variable than the common gender suffix, as in trã-(e)t "the tree" versus sno- $\left({ }^{*} e\right) n$ "the snow".

7 The analysis of [ka:kan] in (22a) as the optimal candidate for [[ka:ka]+n] relies on the assumption that the final syllable, in spite of containing a full vowel and a coda nasal, is prosodically parsed as a prototypical $\beta$ word, see footnote 5 above. 
candidate (23a), whose only merit in to satisfy ONSET, while violating the demands to preserve the prosodic shape of the base or the imperative to have a syllabic suffix. Candidate (23c) gives a clear signal that satisfying ALING_L-R has no bearing in Swedish.

(23) soffan

\begin{tabular}{|c|c|c|c|c|}
\hline$\{$ 'sof:a+n\} & ONSET & OO/p-type & HAVE- $\sigma$ & ALIGN_L-R \\
\hline a. ['sof:an] $\sqrt{ }$ & & \#8 & $*$ & $*$ \\
\hline b. ['sof:a.n] & * & & & * \\
\hline c. ['sof:a:.n] & * & * & & \\
\hline
\end{tabular}

\subsection{Norwegian}

Norwegian departs from Swedish by demoting ONSET under HAVE- $\sigma$. This is justified if we compare Norwegian snøen in (25a) with Swedish snön in (21a).

(24) baren

\begin{tabular}{|l||l|l|}
\hline \{ba: $r+\mathrm{n}\}$ & HAVE- $\sigma$ & ONSET \\
\hline a. [ba::rn] $\sqrt{ }$ & & \\
\hline b. [ba: $r n]$ & $*$ & \\
\hline
\end{tabular}

(25) snøen

\begin{tabular}{|l||l|l|}
\hline$\{$ snø: + n\} & HAVE- $\sigma$ & ONSET \\
\hline a. [snø:n] $\quad \checkmark$ & & $*$ \\
\hline b. [snø:n] & $*$ & \\
\hline
\end{tabular}

Like Swedish, Norwegian does not let ALIGN_L-R exert its force.

(26) bollen

\begin{tabular}{|c|c|c|c|c|}
\hline$\left\{{ }^{2}\right.$ bol: $\left.: ə+n\right\}$ & ONSET & 00/p-type & HAVE- $\sigma$ & ALING_L-R \\
\hline a. [ [2bol:n] $\sqrt{ }$ & & ( & & \\
\hline b. [2bol:en] & & * & $*$ & * \\
\hline c. [2bol:c:.n] & * & : * & & 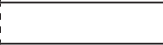 \\
\hline d. [2bol:ə.n] & * & $i$ & & $*$ \\
\hline
\end{tabular}

As expected, disyllabic forms only differ from Swedish with respect to the behavior of -n- when the suffix creates hiatus - compare (27a) and (23a) above.

8 I am assuming that kakan but not soffan is a $\beta$ word. If soffan is a $\beta$ word, then (23a) should not have a violation mark w.r.t. OO/p-type. Nothing depends on this decision for tableau (23). 
(27) sofaen

\begin{tabular}{|c|c|c|c|c|}
\hline$\left\{{ }^{1} \mathrm{so}: \mathrm{fa}+\mathrm{n}\right\}$ & OO/p-type & HAVE- $\sigma$ & ONSET & ALIGN_L-R \\
\hline a. ['so:fa.n] $\sqrt{ }$ & & 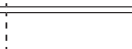 & $*$ & * \\
\hline b. ['so:fan] & $*$ & :* & & : \\
\hline c. ['so:fa:.n] & $*$ & 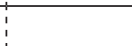 & & 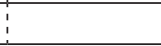 \\
\hline
\end{tabular}

\subsection{Danish}

Everything seems to point out to Danish as the source of the Norwegian preference for syllabic $-\mathbf{n}$ in most contexts, even though Norwegian and Danish could have undergone a similar change by independent routes. This is certainly a question that deserves some clarification, but this is obviously beyond the limits of this paper. The obvious conclusion is that Danish and Norwegian share the subhierarchy HAVE- $\sigma$ > ONSET, synchronically speaking.

In any case, the defining fact in Danish, from a Scandinavian perspective, is that suffixation, as in Aixininca (§3), provokes prosodic alternations, especially notorious whenever the last syllable of the indefinite bases contains a full vowel. In (28), the unstressed stem-final syllable receives secondary stress and, if need be, both vowel lengthening and stød.

(28) Prosodic augmentation of stem-final syllables without primary stress
a. turban-turbanen
['t ${ }^{\mathrm{h}}$ ue्wban]
['t $\left.{ }^{\mathrm{h}} \mathrm{ue}, \mathrm{ban}_{0}^{\mathrm{T}} \mathrm{n}\right]$
b. nectar-nektaren
['negith:]
['neg, ${ }^{\mathrm{h}} \mathrm{a}^{2} \mathrm{n}$ ]
c. sofa-sofaen
['so:fa]
['so: $\left.\mathrm{fre}^{2} \mathrm{n}\right]$
d. vindue-vinduet
['vendu]
['ven, du $\left.\mathrm{u}^{\mathrm{P}} \mathrm{y}\right]$

Along the lines of $\S 3$, these prosodic changes obey the ALIGNMENT conditions of the suffix, requiring a specific prosodic structure on the base, but not stød per se. ALIGN_L$\mathrm{R}$ (suffix, foot), demands that the definite suffix attaches to the right of a heavy syllable. Stød appears to respect the Stød Principle - a pillar of the grammar of stød in BASBØLL 2005, which can be summarized as "assign stød to any heavy syllable with at least secondary stress". Unlike Swedish or Norwegian, the constraint ALIGN_L-R (suffix, foot) dominates OO/prosodic_type in Danish, so that unstressed syllables can recieve secondary stress, and extra length.

(29) sofaen

\begin{tabular}{|l||l||l|l||l|l|}
\hline$\{$ 'so:fa+n\} & OO/p-type & ALIGN_L-R & HAVE- $\sigma$ & OO/p-type & ONSET \\
\hline \hline a. ['so: fæ:?.n] $\sqrt{ }$ & & & & $*$ & $*$ \\
\hline b. ['so: fan'] & & $*$ & $*$ & $*$ & \\
\hline c. ['so: fæ:?n] & & & $*$ & $*$ & \\
\hline d. ['so:fa.n] & & $*$ & & $*$ \\
\hline
\end{tabular}

Only disyllabic words with a final schwa syllable are exceptions to the ALIGNMENT requirement that the suffix follow a heavy syllable. We will model this state of affairs with an indexed version of $\mathrm{OO} /$ prosodic_type, preventing prosodic augmentation when the 
base is paroxytonic and does not contain a full vowel in its final syllable. Only when the base belongs to that prosodic type is $\mathrm{OO} / \mathrm{p}^{-t_{y p e}}$ active.

(30) bollen

\begin{tabular}{|c|c|c|c|c|c|}
\hline$\{b \wedge l ə+n\}$ & OO/p-type ${ }_{\beta}$ & ALIGN_L-R & HAVE- $\sigma$ & 00/p-type & ONSET \\
\hline a. ['b^ln] $\sqrt{ }$ & & & 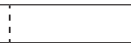 & & \\
\hline 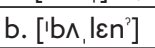 & $*$ & $*$ & $3 *$ & $*$ & \\
\hline 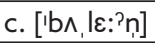 & * & & 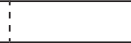 & * & $*$ \\
\hline d. ['b^lə.n] & & $*$ & 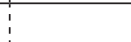 & & * \\
\hline
\end{tabular}

\subsection{Voldby, North Djursland (DK)}

The traditional dialect spoken in North Djursland in the first half of the previous century, as transcribed by Kristian Hald, and further analysed by Inger EJSKJÆR (1974), generalizes the effects of the ALIGNMENT constraint to all disyllables. In addition to the set of stød alternations of mainstream Danish, see (28) above, in North Djursland weak unstressed syllables without a full vowel also receive secondary stress when the definite suffix follows.

(31) Morpheme-stød at large. (IPA version of Ejskjær's 1974 DANIA transcriptions)

\begin{tabular}{|c|c|c|c|c|}
\hline & Indef.sg. & Def.sg. & Indef.pl. & Def.Pl. \\
\hline a. kejser & ['keI:sə] & ['keIn:sq:?n] & ['keI:sə] & 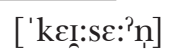 \\
\hline b. bolle & ['boli] & ['boli:?n] & ['bolio] & ['bolic:?n] \\
\hline dverg & ['dvær'o] & ['duær $\left.{ }^{2} \mathrm{o}:^{?} \mathrm{n}\right]$ & ['dowær? & ['duæro: $\left.{ }^{2} n\right]$ \\
\hline harve & ['haro] & ['haro:?n] & ['haro] & ['haro:?n] \\
\hline
\end{tabular}

Inger Ejskjær concluded that the North Djurslandic pattern was the most curious stød. For us, it is just an expected guest, coming to fill up one of the vacant places left by the free recombination of a few universal principles. Unlike in common Danish, the ALIGNMENT constraint now dominates any kind of $\mathrm{OO} / \mathrm{p}$-type constraint.

(32) <bollen>

\begin{tabular}{|c|c|c|c|c|c|}
\hline$\{b \wedge l i+n\}$ & & ALIGN_L-R & HAVE- $\sigma$ & OO/p-type & ONSET \\
\hline a. ['bı li:?.n] & $\sqrt{ }$ & & & * & ; * \\
\hline b. ['b^, lin'] & & $*$ & $*$ & * & 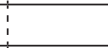 \\
\hline c. ['b^ li.n] & & $*$ & & . & 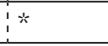 \\
\hline
\end{tabular}

The analysis of this apparently problematic augmentation of weak syllables in front of the definite suffix is nevertheless consistent with the general prosodic profile of Jutlandic dialects, where disyllables of the $\beta$-type, with final levissima, had long lost their status as a major prosodic type (RINGGAARD 1970).

(33) <sofaen>

\begin{tabular}{|c|c|c|c|c|c|}
\hline$\{$ so:fə+n\} & & ALIGN_L-R & HAVE- $\sigma$ & 00/p-type & ONSET \\
\hline a. ['so: fe:?.n] & $\sqrt{ }$ & & 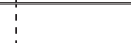 & * & $*$ \\
\hline b. ['so: ffen'] & & 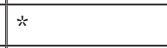 & $: *$ & $*$ & 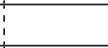 \\
\hline c. ['so: fe:?n] & & & $*$ & $*$ & 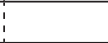 \\
\hline
\end{tabular}


The analysis of the North Djurslandic system is nevertheless incomplete, since nothing in the hierarchy used in (33) precludes the potential candidate ['so:fn] from being the optimal candidate. I will now suggest that the constraint ALIGN_R(stem,p-word), see (16c) and the analysis of Axininca in §3, also plays a role in North Djursland. But this, as well as other proposals along the paper, must be substantiated with further research.

(34) 〈sofaen>

\begin{tabular}{|c|c|c|c|c|c|}
\hline$\{$ 'so:fə+n\} & ALIGN_L-R & ALIGN_R & HAVE- $\sigma$ & OO/p-type & ONSET \\
\hline a. ['so: fe:?.n] $\quad \sqrt{ }$ & & & 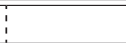 & * & : * \\
\hline b. ['so:fn] & & $*$ & 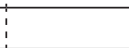 & & $\begin{array}{l}3 \\
\vdots \\
\vdots\end{array}$ \\
\hline
\end{tabular}

\section{Conclusions}

The map of prosodic alternations in Mainland Scandinavian is far from complete, its main features barely drawn on the parchment. It is nevertheless my hope that the analysis provided here may inspire future work on linguistic variation, typology and change in an integrated fashion. The factorial typology below provides a preliminary hypothesis to pursue progress in the always exciting study of morphologically-conditioned prosody in Scandinavian. However, progress must be integrated with similar steps in all areas of grammar, as reviewed in $§ 2$. To the extent that integration is possible, progress will remain or evaporate.

(35) Prosodic typology of Mainland Scandinavian, realization of definite suffixes.

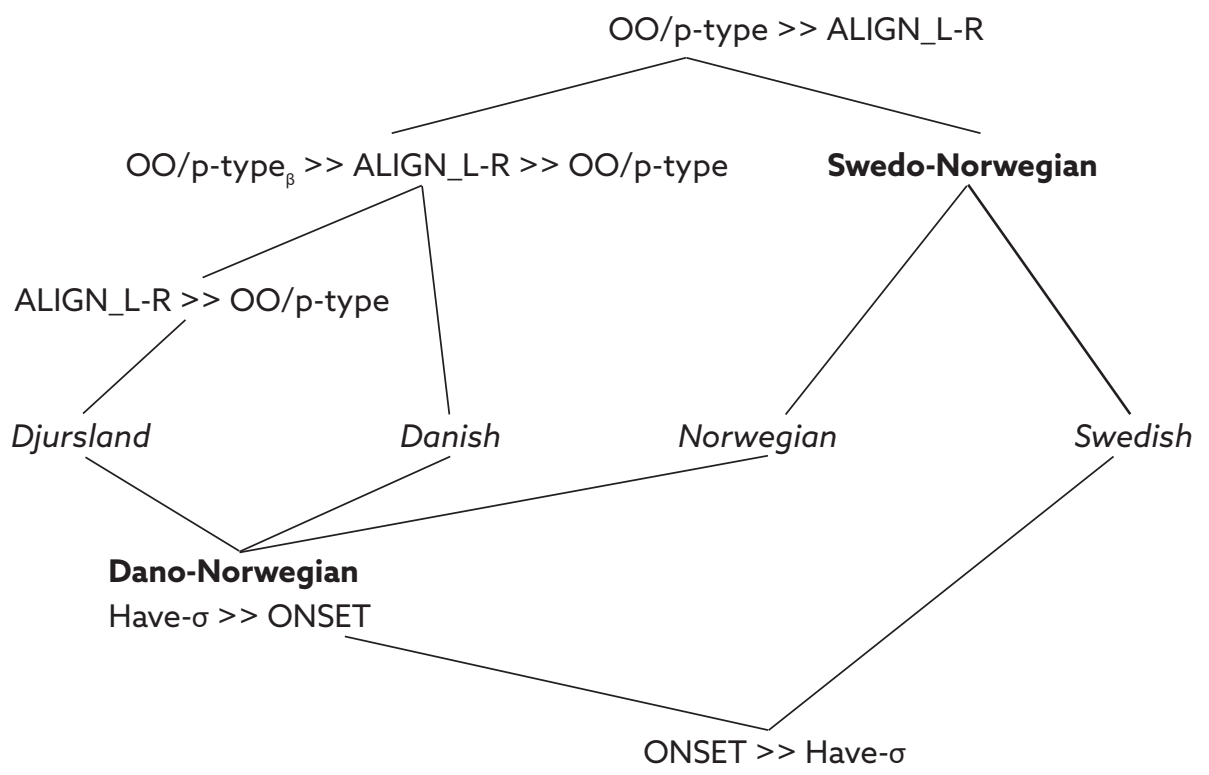




\section{References}

ANDERSEN, Poul \& Louis HJEMSLEV (1967): Fonetik. Copenhagen: Rosenkilde og Bagger.

BASBØLL, Hans (2005): The Phonology of Danish. New York: Oxford University Press.

BASBØLL, Hans (2008): Stød, Diachrony, and The Non-Stød Model. North-Western European Language Evolution. Vol54/55 October 2008: 147-189

DAHL, Östen (2012): Grammaticalization in the north. University of Stockholm.

EJSKJÆR, Inger (1974): Morphemestød i dialekten i Voldby. Festskrift til Kristian Hald

EJSKJÆR, Inger (1990): Pitch accent and stød in Danish dialects. Acta Linguistica Hafniensia.

GRØNNUM, VÁZQUEZ-LARRUSCAÍN \& BASBØLL (2013): Danish stød: Laryngealization or tone? Phonetica 70(1-2).

HELLELAND, Botolv \& Eric PAPAZIAN (1981): Norsk Talemål. Oslo: Fabritius.

KRISTOFFERSEN, Gjert (1991): Aspects of Norwegian Syllable Structure. Dissertation. UiTroms $\varnothing$.

KRISTOFFERSEN, Gjert (2000): The Phonology of Norwegian. Oxford, UK: Oxford University Press.

KRISTOFFERSEN, Gjert (2007): Bestemt form entall hankjønn. In Akselberg, G \& J. Myking (red) A sjå samfunnet gjennom språket. Heiderskrift til Helge Sandøy på 60-årsdagen 14.06.2007. Oslo: Novus.

LUNDEBY, Einar (1965): Overbestemt Substantiv i Norsk. Trondheim: Universitetsforlaget.

McCARTHY, John (2006): Prosodic Morphology. In Keith Brown (ed.) Encyclopedia of Language and Linguistics. $2^{\text {nd }}$ edition. Elsevier.

McCARTHY, John \& Alan PRINCE (1986): Prosodic Morphology. Technical report. New Brunswick, NJ.

McCARTHY, John \& Alan PRINCE (1993): Generalized Alignment. Yearbook of Morphology: $79-153$.

PAMP, Bengt (1978): Svenska Dialekter. Lund: Bröderna Ekstrands.

PAPAZIAN, Erik \& Botolv HELLELAND (2005): Norsk Talemål. Kristiansand.

PRINCE, Allan \& John McCARTHY (2004/[1993]): Optimality Theory. London: Blackwell.

RIAD, Tomas (2003): Bestämhetssuffixens form och tvåstavigheten. University of Stockholm.

RIAD, Tomas (2009b): Prosodi i suenskans ordbildning och ordböjning, ms. University of Stockholm.

RINGGAARD, Kristian (1970): Danske Dialekter. Århus:

SANDØY, Helge (1985): Norsk Dialektkunnskap. Oslo: Novus.

SANDØY, Helge (1996): Talemål. Oslo: Novus.

SANDØY, Helge (1998): The Diffusion of a New Morphology in Norwegian Dialects. Folia Linguistica XXXII/1-2.

SVENONIUS, Peter (1992): The distribution of definite marking. [DGL-UUM-Report 32]

VANGSNES, Øystein A. (1999): The Identification of Functional Architecture. PhD. University of Bergen.

This paper is based on work done at LANCHART, a research team of the University of Copenhagen, during 2010. Parts of it were presented at the IX Conference on Scandinavian Dialectology held at Uppsala in August 2010 and at the Meeting on Scandinavian Variation held in Reykjavík in October 2010. Many thanks to all the members of the phonetics, sociolinguistics and dialectology groups of the fifth floor at Njalsgade 136 for their help with these materials. Financial support to carry out this work and to attend 
those conferences is also gratefully acknowledged. Special thanks to Frans Gregersen, leader of LANCHART, who sponsored me at the time. I am nevertheless the only one responsible for data checking and theoretical choice.

Miguel Vázquez-Larruscaín / miguel.vazquez-larruscain@hit.no Associate Professor, Institute for Cultural Studies, University College of South-East Norway Hallvard Eikas pl. 1, 3800 Bø i Telemark University College, Norway 